\title{
ERGONOMIA W PRACY PIELĘGNIARKI
}

\section{ERGONOMICS IN NURSE'S WORK}

\author{
Mieczysława Irena Wyderka', Teresa Niedzielska ${ }^{2}$ \\ ${ }^{1}$ Zakład Teorii Pielegniarstwa \\ Akademia Humanistyczno-Ekonomiczna w Łodzi \\ Wojewódzki Specjalistyczny Szpital im. Mikołaja Pirogowa w Łodzi \\ ${ }^{2}$ absolwentka Akademii Humanistyczno-Ekonomicznej w Łodzi
}

DOI: http://dx.doi.org/10.20883/pielpol.2016.5

\section{STRESZCZENIE}

Wstęp. Wymuszona pozycja ciała podczas pracy, dźwiganie ciężarów przekraczających dopuszczalne normy wywołują obciążenie układu ruchu, co prowadzi do powstania mikrourazów, a powtarzane doprowadzają do zwyrodnień powodujących dolegliwości bólowe.

Cel. Celem pracy było uzyskanie odpowiedzi na pytania, czy pielęgniarki znają zasady ergonomii, czy mają warunki, by zasady te stosować w praktyce, jaki wpływ na ich zdrowie ma wykonywana praca, czy odczuwają dolegliwości bólowe ze strony układu ruchu i jak radzą sobie w przypadku ich wystąpienia.

Materiał i metody. Badaniem objęto 100 pielęgniarek pracujących na oddziałach internistycznych i neurologii dwóch szpitali miejskich. Zastosowano kwestionariusz ankiety.

Wyniki. Jako ciężką oceniło swoją pracę $60 \%$ ankietowanych, jako bardzo ciężką - 28\%, umiarkowanie obciążającą - 10\%, tylko 2\% uważało ją za lekka. Według $79 \%$ ankietowanych w miare upływu czasu praca jest coraz bardziej obciążającą fizycznie, zdaniem $13 \%$ warunki pracy nie zmieniają się od lat, a dla $8 \%$ jest coraz łatwiejsza. Na pytanie o udogodnienia pomocne w przemieszczaniu pacjentów $29 \%$ odpowiedziało, że nimi dysponuje, $69 \%$ nie ma takiego sprzętu, a $2 \%$ nie określiło tego.

Wnioski. Pielęgniarki nie mają dostatecznej wiedzy z zakresu ergonomii i nie stosują się do jej zasad. Nieprawidłowo wykorzystują czas na odpoczynek, noszą obuwie dodatkowo obciążające kręgosłup, nie dysponują sprzętem ułatwiającym przemieszczanie chorych, opiekują się nadmierną liczbą pacjentów. Pielęgniarki rzadko zasięgają porady lekarza specjalisty i idą na zwolnienie lekarskie.

SŁOWA KLUCZOWE: ergonomia, pielęgniarka, dolegliwości bólowe kręgosłupa.

\section{Wprowadzenie}

Polskie Towarzystwo Ergonomiczne powstało w 1977 r., chociaż ergonomię w Polsce zaczęto propagować i stosować już w latach 60. Od wielu lat mówi się o ergonomii pracy w środowisku pielęgniarskim. Przeprowadzone badania wykazały, że praca pielęgniarek jest obciążająca fizycznie i powoduje dolegliwości ze strony układu

\section{ABSTRACT}

Introduction. The strained pose of the body during work and lifting weights exceeding allowable standards cause an overload of the human motor system and lead to complex microtraumas. When continued, this results in spondylosis and painful disorders.

Aim. The aim of this paper was to investigate whether nurses know the rules of the ergonomics, whether working conditions allow their practical implementation, what the influence of work on their health is, whether their pain originated from the motor system and how they deal with it.

Material and methods. The survey was conducted in two municipal hospitals among 100 nurses working in internal medicine and neurological wards. The method chosen for research was a questionnaire.

Results. $60 \%$ of respondents rated their job as hard, very hard $28 \%$, moderately aggravating $10 \%$, only $2 \%$ evaluated it as easy. $79 \%$ thought that over time the work is becoming more and more aggravating physically, $13 \%$, that working conditions have not changed for years, and for $8 \%$ it is getting easier. When asked about the facilities useful in moving patients, $29 \%$ answered that they have, $69 \%$ do not have such equipment, and $2 \%$ did not specify. Conclusions. Nurses do not have sufficient knowledge of ergonomics and do not apply their principles, they don't rest or exercise properly, at work they use footwear overloading spine, appropriate equipment for lifting and transferring patients is not available to them and that they take care of excessive number patients on duty. Nurses are seldom consulted by specialists and take sick-leave.

KEYWORDS: ergonomics, nurse, back pain.

mięśniowo-szkieletowego. Ergonomia bada fizyczne możliwości i właściwości człowieka, stwarza takie warunki, metody i organizację stanowisk pracy, aby ją uczynić jak najbardziej wydajną, przyczyniającą się do rozwoju duchowego i fizycznego, dającą większą satysfakcję, zapewniającą bezpieczeństwo i wygodę oraz chroniąca zdrowie człowieka. Jest nauką badającą relacje człowiek 
- technika i ma związek z takimi dziedzinami wiedzy jak: bezpieczeństwo i higiena pracy, ochrona pracy, antropologia, medycyna pracy. Technika nie ma służyć samej sobie, ale ma zaspokajać oczekiwania człowieka. To warunki pracy mają być dostosowywane do człowieka, a nie człowiek do warunków pracy [1]. Prawo nakłada na pracodawcę nakaz zachowania wymogów ergonomii w miejscu pracy. Zapewnienie bezpieczeństwa i higieny pracy jest najważniejszym obowiązkiem pracodawcy, a naruszenie ich podlega karze grzywny. Pracodawcy są odpowiedzialni za ocenę ryzyka w miejscu pracy, wdrażanie środków eliminujących i ograniczających zagrożenia, ich obowiązkiem jest chronić zdrowie i życie pracowników poprzez zagwarantowanie bezpiecznych i higienicznych warunków pracy, wykorzystując osiągnięcia nauki i techniki [2]. Państwowa Inspekcja Pracy może i powinna wydawać zalecenia, które zmuszą dyrektorów placówek ochrony zdrowia do stosowania zapisów Dyrektywy Rady Europy. Wydolność fizyczna rośnie do 20. roku życia, na stałym poziomie utrzymuje się około 5 lat, a potem stopniowo maleje. W wieku lat 40 jest już niższa o 10\%, a w 60. roku życia - o 30-40\% w stosunku do wartości najwyższej. Wydolność fizyczna kobiet jest 20-30\% niższa w porównaniu z wydolnością mężczyzn. Przy ręcznym podnoszeniu masa ciężaru nie powinna przekraczać 20 kg przy pracy dorywczej, czyli 4 razy na godzinę w czasie zmiany roboczej i $80 \mathrm{~kg}$ (włączając w to masę sprzętu) podczas przewożenia na wózkach 2-, 3- i 4-kołowych.

Zawód pielęgniarki jest zdominowany przez kobiety i to one stanowią najliczniejszą grupę zawodową w oddziałach szpitalnych. W zakres ich obowiązków wpisana jest praca fizyczna, do której zalicza się: podnoszenie, przemieszczanie i transportowanie pacjentów, dystrybucję leków, płynów do kroplówek, materiałów opatrunkowych, sprzętu medycznego, środków czystości i dezynfekcyjnych, bielizny, transport pobranego materiału do laboratorium itp. Wszystkie te czynności wymagają dźwigania, przejeżdżania wózkami przez przegrody, chodzenia z obciążeniem, schylania się, długotrwałego stania, pracy w wymuszonych pozycjach, chodzenia po schodach, są powtarzane wielokrotnie w czasie dyżuru dziennego, ale też nocnego, kiedy jest zmniejszona obsada pielęgniarska. Podczas ręcznego przemieszczania i przenoszenia pacjentów oprócz masy ciała dodatkowe obciążenie stanowią podłączona aparatura medyczna, stan świadomości, niewystarczająca przestrzeń, praca w niewygodnych pozycjach, brak regulacji wysokości łóżka, wózka czy leżanki, nieliczny personel, brak współpracy z pacjentem, brak sprzętu pomocniczego. Stan techniczny wózków, zmiana kierunku ruchu, pokonywanie nierówności, progów, wąskich przestrzeni, pochylni, odsuwanie sprzętów stojących na drodze - wszystko to wiąże się z nadmiernym obciążeniem [3, 4]. Materiały opatrunkowe, sprzęt medyczny, płyny pakowane są w niewygodne do uchwycenia pudła, które trzeba przewieźć z magazynu, a następnie rozpakować i poukładać w szafach na półkach o różnej wysokości i głębokości. Sprzęt medyczny, taki jak stojaki do kroplówek, defibrylatory, inhalatory, pompy infuzyjne, butle z tlenem, zestawy do pomocy w nagłych przypadkach, wymagają przetransportowania lub przeniesienia z odległych miejsc. Brak współpracy i komunikacji z innymi członkami zespołu wydłuża czas i utrudnia wykonanie czynności. Nieczytelne zlecenia lekarskie wymagają poszukania lekarza i zweryfikowania wytycznych. Częste zmiany zleceń lub zlecenia do natychmiastowego wykonania powodują, że przerywa się jedną czynność, by wykonać inną [5]. Silne zaangażowanie emocjonalne przyspiesza uczucie zmęczenia, a to prowadzi do obniżenia koncentracji uwagi, zwolnienia reakcji na bodźce i rytmu pracy oraz pogarsza koordynację nerwowo-mięśniową. Praca zmianowa i w godzinach nocnych rozregulowuje rytm biologiczny, co ma niekorzystny wpływ na samopoczucie, na życie rodzinne i społeczne, zaburza sen, odpoczynek i pozazawodową aktywność fizyczną, wzmagając występowanie przewlekłych dolegliwości bólowych pleców. Praca w nocy jest przyczyną chorób ze strony układu krążenia, pokarmowego, hormonalnego, nerwowego. Osoby pracujące w nocy częściej zapadają na chorobę wieńcową i nadciśnienie tętnicze. Nieregularne spożywanie posiłków czy jadanie nocą są przyczyną choroby wrzodowej, powodują zgagę, zaburzenia trawienia, brak apetytu lub nadmierny apetyt - ten ostatni jest przyczyną otyłości, a nadwaga wzmaga obciążenie układu kostno-stawowego i mięśniowego. Osoby z cukrzycą mają większe problemy z wyrównywaniem poziomu glukozy, występują wahania hormonów kory nadnerczy, tarczycy. Kobiety częściej mają zaburzenia miesiączkowania, a to z kolei prowadzi do problemów z zajściem w ciążę, jest większe ryzyko poronienia. Zaburzenia w wydzielaniu melatoniny mogą zwiększać ryzyko zachorowania na raka sutka, jelita grubego, jajnika i endometrium. Brak snu powoduje rozdrażnienie, jest powodem konfliktów ze współpracownikami, prowadzi do nerwic, stanów lękowych, lekomanii, zwiększa podatność organizmu na uzależnienia [6].

Do oceny warunków pracy służą tzw. ergonomiczne listy kontrolne, które mogą być modyfikowane i przystosowywane do specyfiki każdego zakładu pracy. Przewlekłe zespoły bólowe kręgosłupa, na które tak często skarżą się pielęgniarki, należą do chorób parazawodowych. Nie są one jednak wpisane na listę chorób zawodowych. Załącznik Międzynarodowej Organizacji Pracy Nr 194 z dn. 20 czerwca 2002 r. przewiduje aktualizację 
wykazu chorób zawodowych o inne choroby związane z warunkami środowiska pracy, podczas kiedy w Polsce zgodnie z Rozporządzeniem Rady Ministrów z dnia 30 czerwca 2009 r. (...) obowiązuje zamknięty wykaz chorób zawodowych i nie podlega on weryfikacji.

Pielęgniarki często wykazują się nieergonomicznymi zachowaniami, co wynika z braku wiedzy, z pośpiechu albo z niedbalstwa. Najczęstsze błędy to: niewłaściwa pozycja, niewłaściwy chwyt, złe nawyki ruchowe, brak wykorzystania sprzętu ułatwiającego pracę. Błędem jest wykonywanie czynności w pochyleniu z jednoczesnym skrętem tułowia w bok, niekiedy takie zachowanie jest wymuszone brakiem przestrzeni, ale często wypływa ze złych nawyków. Inny błąd to podciąganie pacjenta, podczas kiedy nogi stoją w jednym miejscu - w takiej pozycji całe obciążenie przenosi się na kręgosłup, a jeśli ten manewr wykonuje się z dala od chorego, mięśnie kończyn górnych zostają nadmiernie rozciągnięte. Nieodpowiednie jest chwytanie pacjenta pod pachy, które wymusza pochylenie z rotacją kręgosłupa i przenosi ciężar na ręce. Obejmowanie przez pacjenta szyi pielęgniarki podczas podnoszenia obciąża nadmiernie kręgosłup szyjny. Zamiast podnieść łóżko pacjenta, pielęgniarki pochylają się, by wykonać potrzebne zabiegi. Nie korzystają z dostępnych przy łóżkach taboretów w czasie karmienia, pobierania materiału do badań, wykonywania iniekcji, mierzenia ciśnienia czy choćby rozmowy z pacjentem. Noszą niewygodne, ograniczające ruchy ubranie, chodzą w klapkach z wąskimi paskami, drewniakach czy butach na wysokich obcasach, które stanowią utrudnienie w czasie przemieszczania pacjenta i zagrożenie w przypadku utraty przez niego równowagi. Wreszcie nie wykorzystują należycie ustawowej przerwy w pracy. Zamiast na regenerowanie sił przeznaczają ją na papierosa, a niekiedy w ogóle tej przerwy nie wykorzystują, połykając w biegu kanapkę między jedną czynnością a drugą [1]. Choć w Polsce obowiązuje nowoczesny model pielęgnowania w postaci stosowania się do standardów europejskich w prowadzeniu dokumentacji pielęgniarskiej, zdobywania wiedzy medycznej i wciąż nowych uprawnień przez pielęgniarki, to jednak nadal - pozbawione ułatwień technicznych chroniących zdrowie zarówno pielęgniarki jak i pacjenta - podnoszenie, przenoszenie i przemieszczanie pacjentów należą do obowiązków pielęgniarek.

\section{Materiał i metody}

Badanie na temat znajomość zasad ergonomii i jej stosowania zostało przeprowadzone wśród pielęgniarek pracujących w dwóch szpitalach miejskich, w oddziałach chorób wewnętrznych i neurologii. Jako narzędzie badawcze posłużył kwestionariusz ankiety własnego autorstwa, zawierający 38 pytań. Analizowana grupa pielęgniarek była w wieku od 25 do 55 lat, w tym $33 \%$ było w przedziale od 31. do 40. roku życia, $44 \%$ miało ukończone 40 lat, powyżej 50. roku życia było $21 \%$, tylko $2 \%$ miało 25 lat.

\section{Wyniki}

W zakładach opieki zdrowotnej występują liczne czynniki szkodliwe i niebezpieczne, które mogą wpływać na zdrowie pracującego personelu. Wśród zawodów medycznych pielęgniarki narażone są szczególnie na niekorzystny wpływ pracy zawodowej na zdrowie. Niestety, w Polsce, mimo dobrze sformułowanych aktów prawnych, rzeczywistość w zakresie profilaktyki w warunkach pracy zawodowej pozostawia wiele do życzenia. Jak wynika z badań własnych, aż $65 \%$ pielęgniarek było w wieku powyżej 40 lat, co oznacza, że ich zdolność do wysiłku fizycznego i możliwości regeneracyjne są obniżone o $10-40 \%$. Po menopauzie siła mięśniowa jest nawet o 54\% niższa w porównaniu z jej najwyższą wartością osiąganą w wieku 20 lat. Jeszcze 7-8 lat temu przeważały pielęgniarki, które nie ukończyły 40. roku życia. Wzrost średniej wieku pielęgniarek można tłumaczyć tym, że jest mniejsze zainteresowanie zawodem, część rezygnuje z niego lub wyjeżdża za granicę do pracy. W badanej grupie $86 \%$ było po liceum i studium medycznym, 12\% miało ukończony licencjat, a tylko $2 \%$ posiadało tytuł magistra pielęgniarstwa. Badając pielęgniarki pracujące w poznańskich szpitalach, uzyskano podobne wyniki. Opublikowano je na łamach „Medycyny Pracy” w 2004 r. (nr 5). Nasuwa się przypuszczenie, że w kraju pozostają pielęgniarki po liceum medycznym, a częściej wyjeżdżają osoby z wyższym wykształceniem. Przebadana grupa to osoby ze stażem od 1 do 35 lat pracy w zawodzie. Najliczniejszą grupą były pielęgniarki pracujące od 21 do 35 lat (54\%). Od 11 do 20 lat pracy miało $36 \%$, a najmniej, czyli 10\%, było osób o najwyżej 10-letnim stażu. W równoważnym systemie pracowało 79\%, pozostałe - rano. Powyższe dane wskazują, że zdecydowana większość pielęgniarek pracujących na ciężkich oddziałach szpitalnych, bo do takich zaliczają się oddziały internistyczne i neurologiczne, ma średnią wieku 43,7 roku, staż pracy - od 21 do 35 lat i pracuje w systemie równoważnym. Ze względu na zdolności adaptacyjne organizmu osoby powyżej 45 . roku życia nie powinny pracować na dyżurach nocnych. Za niecałe 2 lata, gdyby kierować się powyższymi zaleceniami, zabrakłoby pielęgniarek do pracy w systemie równoważnym. Pielęgniarki lubią swoją pracę, a świadczy o tym fakt, że pracują w zawodzie po kilkadziesiąt lat. Zapytane o to udzielały przeważnie twierdzącej odpowiedzi (96\%); tylko $2 \%$ podało, że nie lubi swej pracy a $2 \%$ było niezdecydowanych.

Aby dowiedzieć się, jak pielęgniarki są obciążone pracą, zadano pytania m.in. o liczbę chorych w oddzia- 
le. Z udzielonych odpowiedzi wynika, że część miała pod swoją opieką 10-20 pacjentów, ale ponad połowa - od 21 do 54 na dyżurze, liczba chorych leżących i wymagających opieki wahała się od 3 do 15, aż 63\% opiekowało się pacjentami leżącymi na korytarzach. Większość pełniła dyżury z koleżanką pielęgniarką, ale aż 13\% miało samodzielne dyżury albo pielęgniarki dyżurowały z innymi członkami zespołu leczniczo-terapeutycznego, którzy niechętnie włączali się do pomocy. Jako ciężką oceniło swoją pracę $60 \%$, bardzo ciężką $28 \%$, umiarkowanie obciążającą - 10\%, tylko $2 \%$ uważało ją za lekką. Według $79 \%$ w miarę upływu czasu ich praca jest coraz bardziej obciążającą fizycznie, 13\% uważało, że warunki pracy nie zmieniają się od lat, a dla $8 \%$ jest coraz łatwiejsza.

O obciążeniu pracą świadczy także wyposażenie oddziału w sprzęt, np. urządzenia do przemieszczania pacjentów, dostęp do łóżka pacjenta, przestrzeń wokół niego i możliwość bezkolizyjnego jeżdżenia z/do sali. Więcej niż połowa odpowiedziała, że ma do dyspozycji sprzęt o regulowanej wysokości i na kółkach, m.in. krzesła, stojaki do kroplówek, szafki przyłóżkowe, wózki do przewożenia w pozycji leżącej. Nieco mniej, bo $44 \%$, mało mobilne defibrylatory, zestawy do pierwszej pomocy. Jeśli chodzi o dostęp do łóżka pacjenta z trzech stron, miało go 38\%, z jednej strony - 33\%, pozostałe musiały odstawić inny sprzęty. Najczęściej tóżka były mobilne, co deklarowało $73 \%$, ale zdarzały się przypadki, że albo kółka były niesprawne, albo drzwi za wąskie, co uniemożliwiało wyjazd z sali i wtedy trzeba było przenosić pacjenta na wózek; według 8\% trudność sprawiały również progi i nierówności. Na pytanie o udogodnienia pomocne w przemieszczaniu pacjentów $29 \%$ odpowiedziało, że nimi dysponuje, $69 \%$, że nie ma takiego sprzętu, a $2 \%$ nie odpowiedziało. Spośród tych, które miały dostęp do sprzętu ułatwiającego pracę, 73\% stwierdziło, że wszystkie udogodnienia, jak pasy, maty ślizgowe, podnośniki, są używane i bardzo odciążają pracę, 17\% odpowiedziało, że czasami je wykorzystuje, a według $10 \%$ były zbędne i można się bez nich obyć. Z powyższych danych wynika, że chociaż pielęgniarki miały sprzęt ułatwiający opiekę nad pacjentami, to i tak nie wszystkie go wykorzystywały.

O konsekwencjach zdrowotnych, trudnych warunkach pracy świadczyły odpowiedzi na pytania dotyczące dolegliwości bólowych, częstość ich występowania, okoliczności ich występowania i tego, czy ból miał wpływ na wykonywanie pracy. Wszystkie badane odpowiedziały, że w ostatnim miesiącu odczuwały ból kręgosłupa, mięśni lub stawów. Najczęściej wymienianym powodem bólu według 73\% była praca w wymuszonej pozycji i podnoszenie ciężkich przedmiotów lub pacjentów. Praca bez odpoczyn- ku powodowała ból u 56\%, przy rozkładaniu leków - u 19\%, taki sam odsetek miał bóle bez określonej przyczyny, 6\% - przy każdej czynności. Na dolegliwości bólowe ze strony układu kostno-stawowego $21 \%$ skarżyło się codziennie, kilka razy w tygodniu - 33\%, co tydzień - $12 \%$, co miesiąc - $17 \%$, tylko kilka razy do roku taki incydent wystąpił u $15 \%$, a raz w roku u $2 \%$. U 90\% ból prawie utrudniał pracę, dla $6 \%$ praca stawała się niemożliwa, a tylko u $4 \%$ nie przeszkadzał w wykonywaniu pracy.

Połowa badanych potrzebowała kilku godzin odpoczynku, żeby ból ustąpił, kilka minut wystarczało $12 \%$, tylko zmiana pozycji - 35\%, leki przeciwbólowe stosowało $60 \%$. Badane najlepiej odpoczywały w pozycji leżącej, taki sposób wskazało 69\%, ulgę przynosiło siedzenie z uniesionymi nogami dla 27\%, 45\% wskazało na gimnastykę, pływanie i uprawianie innych sportów, ale tylko 6\% deklarowało, że uprawia sport. Mimo częstych i dotkliwych bólów pielęgniarki rzadko przebywały na zwolnieniach lekarskich, można przypuszczać, że jedynie wtedy, kiedy ból uniemożliwiał im pracę i one stanowiły 6\%. Co czwarta badana korzystała z zabiegów rehabilitacyjnych, a z porady lekarza specjalisty - tylko 17\%. Żadna z nich nie skorzystała z leczenia sanatoryjnego. Jeśli chodzi o dostęp do usług medycznych, co piąta uważała, że jest utrudniony, ale większość, bo $68 \%$, nie widziała żadnych trudności, dla $8 \%$ był łatwiejszy niż dla innych pacjentów. Badane w większości (77\%) z bólem najczęściej radziły sobie same. Pielęgniarki znają działanie leków przeciwbólowych, mają do nich łatwiejszy dostęp, mogą też skorzystać z koleżeńskiej porady lekarzy, z którymi pracują, może dlatego tak rzadko same bywają pacjentkami.

Zapytano badane o sposób spędzania wolnego czasu. Najczęściej odpowiadały, że przeznaczają go na odespanie przepracowanych nocy i wykonanie zaległych prac w domu, 33\% brało dodatkową pracę zarobkową i taki sam odsetek dokształcał się, 19\% było wzywane do pracy na zastępstwo. Tylko 6\% uprawiało sport. Niewielka część zaznaczyła, że przeznacza ten czas tylko dla siebie i zapomina o pracy.

Praca na większości stanowisk w ochronie zdrowia często wymaga indywidualnego sposobu wykonywania czynności, przy których nie da się wykorzystać najnowszych osiągnięć technologicznych. Przeciążenia układu ruchu wynikają najczęściej z konieczności podniesienia, podtrzymywania, przeniesienia określonego obiektu. Termin „ergonomia” znało 56\% respondentek, przy czym tylko 37\% prawidłowo opisało jego znaczenie. Jedna czwarta badanych przyznała się, że nie wie, jaka jest dopuszczalna masa podnoszonych ciężarów, $40 \%$ odpowiedziało prawidłowo, a 35\% podało wartość o połowę mniejszą. Pacjent ważący powyżej $80 \mathrm{~kg}$ wraz 
z wózkiem nie powinien być przewożony przez jedną pielęgniarkę, ale o tym wiedziało tylko $44 \%$ pytanych. Jedna trzecia badanych miała dostęp do sprzętu do przemieszczania chorych. Powstaje pytanie, czy pielęgniarki potrafią posługiwać się tym sprzętem. Otóż 75\% miało taką wiedzę, ale tylko $51 \%$ było przeszkolone w bezpiecznym przemieszczaniu chorych i obsługi, $35 \%$ chciałoby, aby takie szkolenia odbywały się cyklicznie i prawie taki sam odsetek samodzielnie poszukuje informacji. Spośród badanych 19\% oceniło, że ich wiedza była wystarczająca do wykonywania pracy, a 10\% nie miało możliwości zastosowania jej w praktyce. Co czwarta pielęgniarka nie znajdowała czasu na szkolenia. Z odpowiedzi wynika, że najbardziej obciążające układ mięśniowo-stawowy są prace wykonywane niewłaściwie z powodu braku dostępu do sprzętu, a na drugim miejscu należy wymienić niewystarczającą wiedzę na ten temat. Rodzaj obuwia ma ogromny wpływ na stabilizację stopy, zapobieganie urazom, zmęczeniu i bólom nóg. Chodzenie po twardym podłożu wzmaga te dolegliwości, a klapki czy buty na wysokim obcasie mogą być przyczyną urazów. Jednak $21 \%$ chodziło w pracy w drewniakach, aż $67 \%$ nosiło klapki, 1\% - wysokie obcasy, a tylko 11\% miało dobrze opinające stope buty z wkładkami ortopedycznymi.

Pytania dotyczyły także zorganizowania stanowisk pracy i dostępności najbardziej potrzebnego sprzętu medycznego. Tylko $48 \%$ miało go w zasięgu ręki. Niestety ponad połowa musiała udać się po niego do odległego pomieszczenia, czasami szukać, bo został przełożony. Często po ww. sprzęt trzeba było schylać się do dolnych szafek albo sięgać, używając do tego celu innego sprzętu, zdarzało się też, że był zastawiony innymi przedmiotami. Większość badanych, czyli 79\%, widziała potrzebę usprawnienia swojego stanowiska pracy, pozostałe były zadowolone z obecnego stanu. Niestety tylko $30 \%$ mogło decydować o jego organizacji, pozostałe stwierdziły, że nie miały na to żadnego wpływu.

Analizując powyższe odpowiedzi, można wysunąć wniosek, że pielęgniarki wbrew temu, co mówią, mogą i powinny usprawniać swoje stanowisko pracy i zadbać o to, by stało się ono bardziej funkcjonalne. Jest szereg prostych i niewymagających dużych nakładów finansowych sposobów pozwalających na zmniejszenie obciążenia fizycznego personelu, niestety, brak dbałości o własne zdrowie i bezpieczeństwo, pośpiech, często złe przyzwyczajenia, ale też brak wsparcia kierownictwa zakładów pracy nie sprzyjają ergonomicznym zachowaniom.

\section{Wnioski}

Badane pielęgniarki miały małą wiedzę na temat ergonomii pracy, większość nie znała ustawowych, do- puszczalnych wartości ciężarów, jakie może dźwigać kobieta. Konsekwencją tego nie zabiegały o to, by ich stanowisko pracy było zorganizowane zgodnie z zasadami ergonomii. Stwierdzono duże braki w wyposażeniu dostosowanym do ich możliwości fizycznych, dysponowały zbyt małą przestrzenią do pracy, co wymuszało przyjmowanie nieodpowiednich pozycji. Na bóle kręgosłupa, stawów i mięśni skarżyła się cała badana populacja pielęgniarek, znikoma część z nich zasięgała porad lekarzy specjalistów i chodziła na zwolnienia lekarskie. Tylko co czwarta skorzystała z zabiegów rehabilitacyjnych, a żadna nie leczyła się w sanatorium. Pielęgniarki zazwyczaj radziły sobie z bólem same i brały leki przeciwbólowe.

Z badań wynika, że niekorzystne warunki pracy, brak dostatecznej wiedzy na temat ergonomii, lekceważenie własnego zdrowia i brak racjonalnego wypoczynku przekładają się na kondycję zdrowotną i fizyczną pielęgniarek. Profilaktykę występowania nieprawidłowości pracy mogłyby stanowić zarówno szkolenia pielęgniarek oraz kadry kierowniczej w zakresie ergonomicznych technik opieki nad pacjentem, jak i wyposażenie w specjalistyczny sprzęt.

\section{Piśmiennictwo}

1. Jóźwiak Z. Ergonomiczne kształtowanie środowiska pracy. Kręgosłup masz tylko jeden. Łódź: Instytut Medycyny Pracy; 2009. 3, 7, 10-12.

2. Cichońska-Marczak M. Ocena ryzyka zawodowego. Mag Piel Położ. 2009; 3: 22- 23.

3. Mielczarek-Pankiewicz E. Problemy zdrowotne pielęgniarek i położnych (2). Mag Piel Położ. 2010; 4: 10-11.

4. Jóźwiak Z. Obciążenia układu mięśniowo-szkieletowego w praktyce pielęgniarskiej. Lek Med Pr. 2007; 9: 10-13.

5. Orłowska W. Ergonomia a ryzyko błędu medycznego. Biuletyn. 2010; 1: 5.

6. Talarska D, Zozulińska-Ziółkiewicz D. Pielęgniarstwo internistyczne. Podręcznik dla studentów medycznych. Warszawa: PZWL; 2009. 360-361.

Artykuł przyjęty do redakcji: 25.07 .2014

Artykuł przyjęty do publikacji: 25.08.2015

Źródło finansowania: Praca nie jest finansowana z żadnego źródła. Konflikt interesów: Autorzy deklarują brak konfliktu interesów.
Adres do korespondencji:
Mieczysława Irena Wyderka
ul. Pływacka 112
94-127 Łódź
tel.: 426804760
e-mail: mwyderka1@wp.pl
Akademia Humanistyczno-Ekonomiczna w Łodzi 